\title{
Cinensaios de Agnès VARda: O documentário Como ESCRITA PARA ALÉM DE SI
}

\author{
Letizia Osorio Nicoli*
}

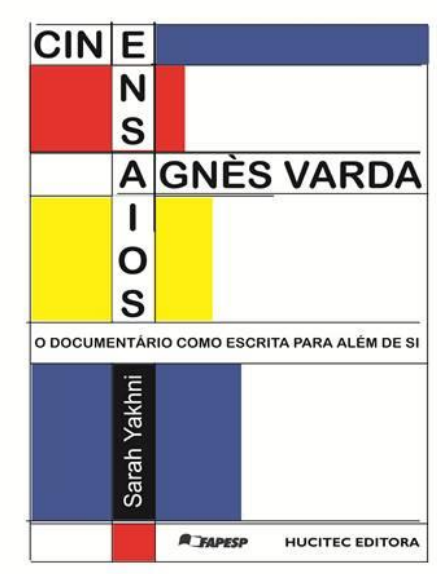

Sarah Yakhni, Cinensaios de Agnès Varda: o documentário como escrita para além de si, Campinas, HUCITEC/FAPESP, 2014. ISBN: 858404003X

A Editora Hucitec, muito oportunamente, lançou, no final de 2014, o livro Cinensaios de Agnès Varda: o documentário como escrita para além de si, de Sarah Yakhni, publicação esta resultante da tese de doutorado defendida pela autora junto ao Programa de Pós-graduação em Multimeios da Unicamp. O livro se dedica à análise da obra de Agnès Varda, cineasta bastante reconhecida e de carreira longeva. A pesquisa de Yakhni, no entanto, traz uma abordagem particular da filmografia da cineasta, centrando-se nos documentários realizados pela diretora entre 1958 e 2004, sob a perspectiva do filme-ensaio. Com isso, a obra de Sarah Yakhni se inscreve em uma tendência de interessantes e contundentes trabalhos que

* Doutoranda. Universidade Estadual de Campinas - UNICAMP, Instituto de Artes, Programa de Pós-Graduação em Multimeios. 13083-854, Campinas, Brasil.

E-mail: letizianicoli@gmail.com 
vêm se dedicando ao ensaio no cinema. Ainda que o conceito não seja novo, chama a atenção que tantos pesquisadores estejam atualmente se voltando para o tema, seja através da análise de filmes mais antigos, seja daqueles tantos que experimentam o formato ensaístico na atualidade.

Em seu livro, Sarah Yakhni não se detém em conceitos e referenciais teóricos para construir uma estrutura rígida que encarcere a obra de Varda. Nos primeiros capítulos, dedicados a apresentar o corpus, o referencial teórico e a metodologia, são introduzidas as principais referências no que diz respeito ao ensaio, iniciando-se pela necessária menção a Michel de Montaigne, salientando a construção do texto do autor como uma reflexão para si mesmo. A obra de Theodor Adorno aporta contribuições para as reflexões sobre a forma do ensaio. No que diz respeito ao cinema, a autora faz questão de referenciar autores brasileiros que se dedicam a pensar o formato ensaístico, como Jean-Claude Bernardet, Arlindo Machado, Consuelo Lins e Francisco Elinaldo Teixeira.

Ao invés de partir das considerações já levantadas por esses autores, no entanto, o ponto de partida de Yakhni é claramente a força de seu corpus. A autora não se limita a enquadrar os filmes numa tessitura de conceitos, e desenvolve as análises de maneira bastante original, trazendo aspectos únicos de cada um dos filmes e do processo de criação de Varda. Ao apresentar sua metodologia, no segundo capítulo, a autora deixa claro o destaque dos filmes como condutores da pesquisa, percebendo cada um deles como "processo criativo autônomo que irá, ele mesmo, informar e fazer vir à tona parâmetros que dialoguem de perto com seu modus operandi” (p. 25). Essas considerações levaram-na a trabalhar com análises individuais, construindo a partir dessas um todo coeso, unidas por uma rede de relações entre elas, bem como com a cineasta e seus processos criativos. Vale ressaltar aqui a força que tais análises adquirem quando Yakhni se debruça sobre os procedimentos de realização de Varda. Desde o princípio, a pesquisadora - ela própria realizadora - revela uma grande sensibilidade 
no tratamento que dispensa à cineasta Varda: ao apresentar a trajetória da diretora, Yakhni relata sua contemporaneidade com a Nouvelle Vague, sua participação nos debates acerca da política dos autores, e seu relacionamento com cineastas como Alain Resnais e Chris Marker. Em seu texto, porém, Yakhni foge da armadilha historicista de considerá-la apenas como parte das divisões e discussões políticas e estéticas do período, dando ênfase às declarações da própria Varda sobre sua formação como cineasta. Após os três primeiros capítulos introdutórios, a obra está organizada a partir das análises fílmicas dos filmes que compõem o corpus: L'opéramouffe (1958); Daguerréotypes (1974-75); Salut les cubains (1963); Ulysse (1982); Ydessa, les ours et etc...(2004); Oncle Yanco (1967); Les glaneurs et la glaneuse (2000); Deux ans après (2002). A cada capítulo, Yakhni desvenda processos de composição dos filmes de Varda que a pesquisadora aproxima da escrita ensaística. Entre os diversos elementos abordados, sobressaem-se idéias como o de "filme-diário" ou "caderno de notas", que reiteram o conceito de ensaio de Montaigne. Já nesse primeiro capítulo (dedicado ao filme mais antigo do corpus), delineia-se um estilo ensaístico de Varda que valoriza a subjetividade do olhar, uma relação familiar com o espaço e a construção da poética na justaposição das imagens. Como Yakhni bem o percebe, a força da construção narrativa não jaz apenas na força independente de cada plano, mas na construção de uma ação que não se dá no eixo-dramático, e sim "num encadeamento de estados emocionais" (p. 59).

Mais adiante, no capítulo dedicado à trilogia Cinevardaphotos (com documentários que têm como dispositivos não apenas fotografias, mas a experiência da cineasta como fotógrafa profissional), Yakhni demonstra como esta constrói narrativas a partir de memórias e divagações acerca de registros imagéticos feitos por ela mesma, no passado. Ao passo que L'opéra-mouffe e Daguerréotypes são cadernos de notas de um presente afetivo e cotidiano, os documentários de Cinevardaphotos são viagens a um 
passado registrado em imagens estáticas. Yakhni ressalta o efeito de distanciamento produzido pela inserção das fotografias nos filmes a partir da obra de Raymond Bellour (1997).

Por último, um capítulo dá conta dos filmes mais recentes que Yakhni apropriadamente caracteriza como "cinema de encontro". Cabe aqui mencionar que a dissertação de mestrado da pesquisadora, intitulada $O E u e$ o Outro no filme documentário: uma possibilidade de encontro dedicava-se a esmiuçar as relações entre documentarista e documentado na construção do filme. Essa experiência anterior se reflete na propriedade com que Yakhni desenvolve o conceito de "cinema de encontro" no livro. A subjetividade, o afeto, o acaso, a performance e o caráter de work in progress na obra de Agnès Varda são percebidos e caracterizados com a sensibilidade de quem já elaborou diversas considerações sobre o tema, tomando como base sua própria experiência como realizadora.

O reconhecimento e o valor do Outro nos documentários de Varda configuram o ponto chave da argumentação de Yakhni. É a partir dessa estrutura do trabalho da cineasta que a pesquisadora defende os filmes como uma escrita "para além de si". Ao contrário do que diz Montaigne sobre o texto ensaístico, a presença do Outro como um sujeito pleno nos documentários do corpus permitiria, para Yakhni, uma fala compartilhada. Com tais considerações, a leitura do livro chega ao seu final como uma experiência rica e sensível, configurando uma contribuição original para as discussões que se desenvolvem atualmente acerca do ensaio no cinema. 